\title{
Detection of the host-specific Bacterioides and Bifidobacteriumsaeculare markers in surface water in Hanam, Vietnam with real-time PCR
}

\author{
Hoa LM, Tram NT, Thi Phuong Mai L, Hai PT, Quynh PD, Dung LP, Nguyen TT, Lien NTP, Nguyen TT, \\ Quyet NT, Hien NT and Thi Thu Ha H*
}

National Institute of Hygiene and Epidemiology, Hanoi, Vietnam

*Corresponding author: Thi Thu $\mathrm{Ha} \mathrm{H}$, National Institute of Hygiene and Epidemiology, 1- Yersin Street, Hanoi, Vietnam, Tel: 84-0904126943,E-mail: htth@nihe.org.vn; hoangha.nihe@gmail.com

Citation: Hoa LM, Tram NT, Thi Phuong Mai L, Hai PT, Quynh PD, et al. (2018) Detection of the hostspecific Bacterioides and Bifidobacteriumsaeculare markers in surface waterin Hanam, Vietnam with realtime PCR. J Health Sci Stud 1(1): 101. doi: 10.15744/2767-9136.1.101

Received Date: December 15, 2017 Accepted Date: May 20, 2019 Published Date: May 22, 2019

\begin{abstract}
The microbiological quality of coastal or river waters can be affected by faecal pollution from human or animal sources. Contamination of fresh produce with pathogenic bacteria can be attributed directly or indirectly through the raw wastewater (domestic, industrial effluents, human and animal excrement). This includes water sources that are routinely used for crop irrigation and produce washing. An efficient MST (Microbial Source Tracking) toolbox consisting of several host-specific markers would therefore be valuable for identifying the origin of the faecal pollution in the environment and thus for effective resource management and remediation. As a result, the need for expanding from traditional techniques to molecular methods has been highly recommended. The aim of the study was to investigate the presence of several host-specific markers in surface water in Vietnam using real-time PCR assay. The study was conducted through collecting 145 river water samples at the two communes (Thuong and Quan Nha Villages) in Ha Nam Province in both wet and dry seasons. The AllBac marker was 21 found at the rate of 79.2\% (57/72) in Quan Nha and 93.2\% (68/73) in Thuong Village, following by the $22 \mathrm{HF}-183$ with the rate of $25 \%$ (18/72) and $44 \%$ (32/73), respectively. The Pig-2-Bac marker was found 23 at the lower rate with 19.2\% (14/72) in Quan Nha Village and 5.55\% (4/72) in Thuong Village. No poultry marker (Bifidobacteriumsaeculare) was detected in water samples at both sampling sites. All these markers were found to be higher in Thuong than in QuanNha Village and in wet than in dry season. The derived results were significant in the evaluation of the quality of surface water and play a vital role for tracking the source of bacterial contamination of the areas where the vegetables come from.
\end{abstract}

Keywords: Real-time PCR; AllBac Marker; Bifidobacteriumsaeculare; Waterway Contamination; Ha Nam

\section{Introduction}

Contamination of waterways with feacal material leads to the dissemination of pathogens, antibiotic resistant bacteria, and excess nutrients that have serious impacts on human and environmental health [1-4]. Major sources of contaminants include human derived sources (sewage leaks or combined sewer overflows), and agricultural sources (animal feeding operations and manure management of agricultural fields) [5]. In addition, domestic animals and wildlife may also contribute to aquatic faecal loads in some watersheds. Thus reduction of aquatic faecal loads and increased protection of human and environmental health depend on distinguishing which of the many possible contaminating sources impact a particular body of water and products grown in contaminated water [6].

Water pollution has been significantly important to know in Vietnam. Untreated water can contaminate crops through irrigation activities. These may bring unhealthy and unsafe food to consumers. Increased public awareness of the health-related and economic impact of water contamination and illness has resulted in greater efforts to apply more sensitive methods of pathogen detection and identification. Advances in molecular biology technology, particularly the real-time PCR, have allowed more reliable bacteria identification and surveillance in not only clinical but also environmental samples. Real-time PCR has become a valuable tool in investigating Microbial Source Tracking (MST) related the faecal bacteria population, have little potential for growth in the environment, and have a high degree of host specificity that likely reflects differences in host animal digestive systems. 
There is a need to increase the awareness of the impact of bacteria which belong to the genus Bacteroides on the water supply in Vietnam. The impact of Bacteroides presenting in human, animal faeces is difficult to assess, primarily due to the lack of a uniform standard and laboratory equipment for monitoring incidence and diagnosis of waterborne illness. Bacterial markers were selected among Bacteroides and Bifidobacterium, two bacterial groups that have been reported to contain host-specific bacterial species [7]. These markers have been widely used to monitor faecal pollution in water and to distinguish human and animal sources [8]. In order to improve water quality, management and remediation plans need methods of identifying faecal pollution sources. Thus, the aim of this study was to use microbial source tracking method (real-time PCR) for detecting and differentiating human and animal pollution in surface water in Vietnam.

\section{Materials and Methods}

\section{Site selection and sampling design}

Yen Bac and Tien Ngoai are communes of the Duy Tien District in Hanam province which is located at about $60 \mathrm{~km}$ southern Hanoi.A total of 145 water samples were collected from rivers in Quan Nha Village, Yen Bac Commune and Thuong Village, Tien Ngoai Commune along the Nhue and Nhue-Day River basin (Figure 1). The sites were selected on the basis of husbandary, aquaculture and agriculture activities which may contribute to the fresh surface water pollution. The population in Thuong Village in 2015 was 478, living in 158 households. This is the village which has high intensity of a small- and medium-scale pig and poultry farms with the average number of 16.1 pig per household and 37.8 chicken per household, relatively. In 2015, the population in Quan Nha Village was 1062, living in 367 households. Most farmers are doing rice, pig and poultry farming. Farms are small-scale and raise 1-20 pigs and 1-10 chickens [9]. The pig and chicken pens are typically located near the house and husbandry wastes are discharged to a common canal, which is connected to the Nhue river. In both villages, the drinking water source is mainly originated from rainy water. Water from dug well or drilled well is used for bathing, cleaning and other household activities. The flushing toilet is the most common type of latrine in these villages. Double-vault latrine is also another type of toilet used at 94 households in Quan Nha and at only 8 households in Thuong Village. Water samples analyzed in this study were collected from each village in two seasons with 72 in Quan Nha (including 33 in wet and 39 in dry season) and 73 in Thuong (including 42 in wet and 31 in dry season), respectively. Seasons were categorized as wet (February to July) and dry (August to January). All samples were tested for Bacteroidales markers as described below.

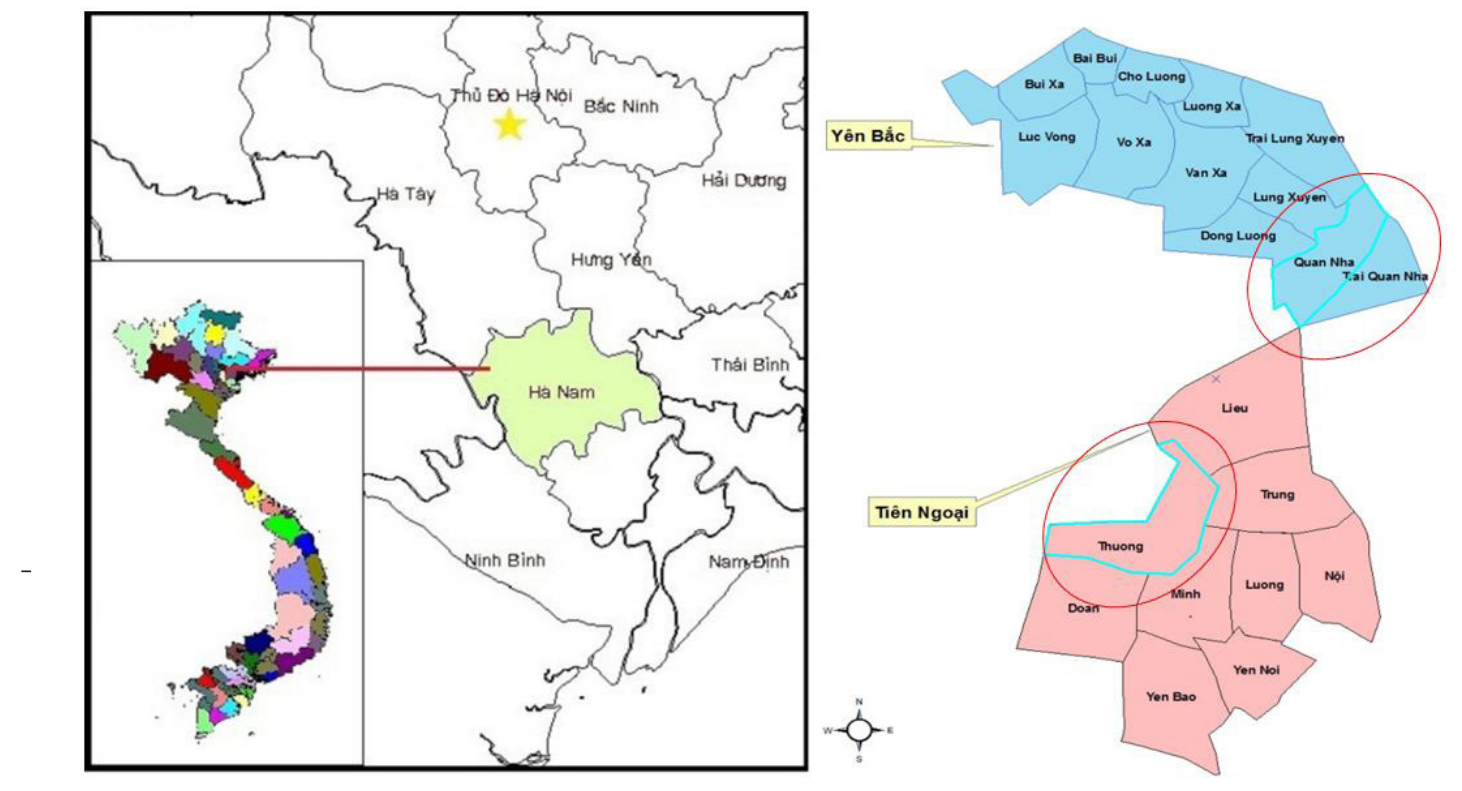

Figure 1: Surface water sampling sites in Ha Nam province

(Source: Luu Quynh Huong. 2014 [10]. PhD thesis and Lien et al. 2015 [11])

\section{Sample collection and processing}

Surface water samples that are used to irrigate rice and vegetable field fill up fishponds and vegetable washing were collected at field sites during daylight hours. One liter of sample was gathered just below the water surface after sterile, wide-mouth and screwcapped 1-L collection bottles were prerinsed twice times in the river. After collection, all samples were stored in a cooling box and transported to the laboratory on the day of sampling for further analysis.

\section{Sample preparation and DNA extraction}

Approximately $200 \mathrm{ml}$ of water samples were filtered through $0.22 \mu \mathrm{m}$ nuclepore track-etch membrane (Whatman, Schleicher and 
Schuell, Germany). Filters were then placed in $0.5 \mathrm{ml}$ of GITC buffer (5M guadinineisothiocyanate; 100mM EDTA, pH 8.0; 0.5\% Sarkosyl) (Cox et al. 2005) and kept at $-20^{\circ} \mathrm{C}$ until extraction. Genomic DNA was extracted using the Fast DNA kit for soil (MP Biomedicals, Illkirsh, France) according to the manufacturer's instructions.

\section{Realtime PCR assay}

All real time quantitatives PCRs were performed using a TagMan@ Universal PCR Master Mix (Applied Biosystems), except the human-specific marker defined by Okabe et al. 2007, which used Applied Biosystems ${ }^{\mathrm{TM}} \mathrm{SYBR}^{\mathrm{TM}}$ green mastermix (Thermo Fisher) [12].

Amplification was performed using an Applied Biosystems 7500 Fast Instrument with software 7500 v2.3. Each reaction was run with the following cycle condition: 1 cycle at $95^{\circ} \mathrm{C}$ for $10 \mathrm{~min}$ followed by 40 cycles of $95^{\circ} \mathrm{C}$ for $15 \mathrm{~s}$ and $60^{\circ} \mathrm{C}$ for $1 \mathrm{~min}$. For poultry marker, the thermal-cycler conditions were as follows: an initial set up of $2 \mathrm{~min}$ at $50^{\circ} \mathrm{C}$, followed by $10 \mathrm{~min}$ at $95^{\circ} \mathrm{C}, 40 \mathrm{cycles}$ of $15 \mathrm{~s}$ of denaturation at $95^{\circ} \mathrm{C}$, and $1 \mathrm{~min}$ of annealing/extension at $60^{\circ} \mathrm{C}$. For SYBR green amplifications, a dissociation step was added to improve amplification specificity.

TaqMan and SYBR green reactions were carried out in a final volume of $25 \mu$ with appropriate final concentrations of primer and probe (Table 1).

\begin{tabular}{|c|c|c|c|c|}
\hline Primer or probe & Primer and probe sequence $\left(5^{\prime}-3^{\prime}\right)$ & $\begin{array}{c}\text { Final } \\
\text { concen } \\
(\text { nmol })\end{array}$ & Reference & Target \\
\hline \multicolumn{5}{|l|}{ AllBac } \\
\hline AllBac296F & GAGAGGAAGGTCCCCCAC & 200 & $\begin{array}{c}\text { Layton } \\
\text { et al. } 2006 \text { [9] }\end{array}$ & $\begin{array}{c}\text { All } \\
\text { Bacteroidales }\end{array}$ \\
\hline AllBac467R & CGCTACTTGGCTGGTTCA & 200 & & \\
\hline AllBac375Bhqr & (FAM)CCATTGACCAATATTCCTCACTGCTGCT(BHQ_1) & 100 & & \\
\hline \multicolumn{5}{|l|}{ HF183 } \\
\hline $\mathrm{HF} 183 \mathrm{~F}$ & ATCATGAGTTCACATGTCCG & 200 & $\begin{array}{c}\text { Seurinck } \\
\text { et al. } 2005[18]\end{array}$ & $\begin{array}{c}\text { Human } \\
\text { Bacteroidales }\end{array}$ \\
\hline HF183R & TACCCCGCCTACTATCTAATG & 200 & & \\
\hline \multicolumn{5}{|l|}{ Pig-2-Bac } \\
\hline Pig-2-Bac163Rm & ACCTCATACGGTATTAATCCGC & 300 & $\begin{array}{c}\text { Mieszkin } \\
\text { et al. } 2009 \text { [13] }\end{array}$ & $\begin{array}{c}\text { Pig-specific } \\
\text { Bacteroidales }\end{array}$ \\
\hline Pig-2-Bac41F & GCATGAATTTAGCTTGCTAAATTTGAT & 300 & & \\
\hline Pig-2-Bac113MGB & (VIC)TCCACGGGATAGCC(NFQ-MGB) & 100 & & \\
\hline \multicolumn{5}{|c|}{ Bifidobacterium saeculare } \\
\hline Bif-F & TTCGGGTTGTAAACCGCTTTT & 900 & $\begin{array}{c}\text { Gómez- } \\
\text { Doñate } \\
\text { et al. } 2012 \text { [5] }\end{array}$ & $\begin{array}{c}\text { Poultry } \\
\text { Bacteroidales }\end{array}$ \\
\hline Bif-R & TACGTATTACCGCGGCTGCT & 900 & & \\
\hline PLprobe & (FAM)GAGAGTGAGTGTACCCGTT(NFQ) & 250 & & \\
\hline
\end{tabular}

\section{Statistical analysis}

Data were analyzed using the SPSS software (Statistical Package for Social Sciences) version 11.0. Data was reported as percentage. The association of bacterial marker positive samples with sampling locations and seasons were tested by chi-square $\left(\chi^{2}\right)$. The $\mathrm{P}$ values of $\leq 0.05$ were chosen statistical significance level.

\section{Results}

Quantitative PCR detections of the human-associated marker (AllBac) was consistant at the two sampling sites (Quan Nha and Thuong Villages) (Table 2). The all-Bacteroides marker (AllBac) was identified in 57 out 72 sample collected (79.2\%) in Quan Nha and 68 out of 73 samples (93.2\%) in Thuong Village. At least one host-specific marker was identified in samples from two sites with no case having multiple markers. The HF-183 marker was identified in 18 of water samples collected in the Quan Nha village (25.0\%) and in 32 of water samples collected in Thuong Village (44\%), respectively. The percentage of water samples which had the Pig-2-Bac marker in Thuong Village 19.2\% $(\mathrm{n}=14)$ and the figure for Quan Nha Village was only 5.55\% ( $\mathrm{n}=4)$. No poultry marker (Bifidobacteriumsaeculare) was detected in water samples at both sampling sites. It was found that AllBac and Pig-2-Bac markers were significantly higher in Thuong than in Quan Nha ( $97.6 \%$ vs $78.8 \%, p=0.018$ and $28.6 \%$ vs $6.1 \%$, $p=0.0025)$. In Thuong village, the Pig-2-Bac marker was significantly higher in wet than dry season (28.6\% vs $6.5 \%$, p=0.005) (Table 4$)$. No statistically significant 
difference was found with all markers between the two seasons in Quan Nha Village (Table 3).

\begin{tabular}{|c|c|c|c|c|c|}
\hline \multirow{2}{*}{$\begin{array}{c}\text { Sampling } \\
\text { time }\end{array}$} & \multirow{2}{*}{ Sampling location } & \multicolumn{4}{|c|}{ Host-specific Bacteroides markers } \\
\cline { 3 - 6 } & & $\begin{array}{c}\text { AllBac } \\
(\%)\end{array}$ & HF 183 (\%) & Pig-2-Bac (\%) & Poultry (\%) \\
\hline Wet & & $\mathrm{p}=0.018$ & $\mathrm{p}=0.25$ & $\mathrm{p}=0.0025$ & - \\
\hline & Quan Nha $(\mathrm{n}=33)$ & $26(78.8)$ & $12(36.4)$ & $2(6.1)$ & $0(0)$ \\
\hline & Thuong $(\mathrm{n}=42)$ & $41(97.6)$ & $22(52.4)$ & $12(28.6)$ & $0(0)$ \\
\hline & Total $(\mathrm{N}=75)$ & $67(89.3)$ & $34(45.3)$ & $14(18.7)$ & $0(0)$ \\
\hline Dry & & $\mathrm{p}=0.52$ & $\mathrm{p}=0.15$ & $\mathrm{p}=1$ & - \\
\hline & Quan Nha $(\mathrm{n}=39)$ & $31(79.5)$ & $6(15.4)$ & $2(5.1)$ & $0(0)$ \\
\hline & Thuong $(\mathrm{n}=31)$ & $27(87.1)$ & $10(32.3)$ & $2(6.5)$ & $0(0)$ \\
\hline & Total $(\mathrm{N}=70)$ & $58(82.8)$ & $16(22.9)$ & $4(5.7)$ & $0(0)$ \\
\hline
\end{tabular}

Table 2: Proportion of water samples positive with host-specific Bacteroidales markers

\begin{tabular}{|c|c|c|c|c|}
\hline Sampling time & \multicolumn{4}{|c|}{ Host-specific Bacteroides markers } \\
\hline & AllBac (\%) & HF 183 (\%) & Pig-2-Bac (\%) & Poultry (\%) \\
\hline & $\mathrm{p}=1$ & $\mathrm{p}=0.056$ & $\mathrm{p}=1$ & - \\
\hline Wet $(\mathrm{n}=33)$ & $26(78.8)$ & $12(36.4)$ & $2(6.1)$ & $0(0)$ \\
\hline Dry $(\mathrm{n}=39)$ & $31(79.5)$ & $6(15.4)$ & $2(5.1)$ & $0(0)$ \\
\hline
\end{tabular}

Table 3: Proportion of water samples positive with host-specific Bacteroidales markers in Quan Nha village between two seasons

\begin{tabular}{|l|c|c|c|c|}
\hline Sampling time & \multicolumn{4}{|c|}{ Host-specific Bacteroides markers } \\
\hline & AllBac (\%) & HF 183 (\%) & Pig-2-Bac (\%) & Poultry (\%) \\
\hline & $\mathrm{p}=0.15$ & $\mathrm{p}=0.14$ & $\mathrm{p}=0.005$ & - \\
\hline Wet $(\mathrm{n}=42)$ & $41(97.6)$ & $22(52.4)$ & $12(28.6)$ & $0(0)$ \\
\hline Dry $(\mathrm{n}=31)$ & $27(87.1)$ & $10(32.3)$ & $2(6.5)$ & $0(0)$ \\
\hline
\end{tabular}

Table 4: Proportion of water samples positive with host-specific Bacteroidales markers in Thuong village between two seasons

\section{Discussion}

The results of this study and previously published research indicate the widespread faecal contamination of river water in Ha Nam over wide range of conditions. AllBac marker was found with the considerable high percentage of the water samples $(79.2 \%$ 93.2\%) examined at the two sampling sites $[13,14]$. This is an agreement with findings in a study done in France where $25 \%-90 \%$ of coastal or river water samples were affected by faecal contamination from human and animal sources [15]. These results suggest that real-time PCR assays provide preliminary faecal source identification in watersheds.

Host-specific qPCR assays has been considered as a rapid tool in assessing faecal contamination in river water and other environments [16]. Advantages include the speed of assays, specificity, reasonable cost, and no need for a cultivation step [17]. In this study, we first applied host-specific qPCR assays for rapid determination of human and animal-originated faecal contamination in surface water. One human and two animal-specific qPCR assays targeting human, pig and poultry were used to identify the extent of household and farm animal faecal contamination in water. These hosts were chosen because they are regarded as major sources of faecal contamination in river water and water used for agriculture.

The findings in our study show that Thuong Village was having the higher proportion of samples positive with host-specific markers. This can be explained that the densely populated pig farming activities were presented in this area may cause the more serious surface water pollution due to the poor animal manure management. On the other hand, sewage and household wastewater was discharged to septic tanks located on each household, or to a common pond or canal. Thus, more widespread faecal pollution of the surface water to the household wells originating from human and animal excreta could be possible, as AllBac, HF-183 and Pig-2-Bac markers were found in 20\% - 93\% of river water samples investigated.

The origin of pollution in the river flowing through the two villages was clearly identified by the HF183 and Pig-2-Bac and by the absence of poultry-specific Bacteroidales. The presence of the human and pig markers indicate that river water in Ha Nam can be frequently impacted by human and animal faecal contamination. Alarmingly, the river water is commonly used for numerous recreational activities including swimming, aquaculture and agriculture activities. In fact, the faecal contamination of vegetables can be caused by fertilization of plants with human and animal waste or indirectly via contaminated water used in crop irrigation. Therefore, the two previously mentioned indicators can be used to detect human and animal faecal contamination either in surface 
water or in leafy vegetable to help minimize public health risk.

Part of the variability observed in the presence of HF-183, Pig-2-Bac may be explained by the half-life occurrence of these two indicators between the two seasons. Since we found the higher number of water samples positive with these markers in the wet than in dry season. This finding was corresponding to the study done by with the view that human-derived faecal bacteria is more likely to be common in the wet season along with increased concentration of wastewater compounds $[18,19]$. In addition, previous observations indicate the presence of extreme low flows during the dry season that significantly decrease the transport of bacterial indicators [20].

In conclusion, the increased public awareness of water pollution and health-related risks is extremely needed. The discharge of waste or polluted water from households or animal farms to common canals, ponds, rivers could contaminate surface and groundwater sources with pathogens through surface run-off, leaching and direct faecal deposition into the water bodies [21]. Also the use of polluted water or waste for vegetable irrigation may pose a risk to human health. Therefore improved animal manure management is essential for reducing the risk of surface and groundwater contamination and sustainable water supply [22].

\section{Acknowledgement}

This research was received a financial support from Pasteur Institute in Paris under the project entitled: "ECOnomic development, ECO system Modifications, and emerging infectious diseases Risk Evaluation (ECOMORE)”.

We thank Ms. Elizabeth N. Lartey, Volunteers for Healthy Animals and Healthy Communities Project, Veterinarians without Boarders for editing the English language of the manuscript.

\section{References}

1. Cinquepalmi V, Monno R., Fumarola L, Ventrella G, Calia C, et al. (2013) Environmental contamination by dog faeces: a public health problemInt J Environ Res Public Health 10: 72-84.

2. Cleaveland S, Laurenson MK, Taylor LH (2001) Diseases of humans and their domestic mammals: pathogen characteristics, host range and the risk of emergence. Philos Trans R SocLond B Biol Sci 356: 991-9.

3. Fairbairn DJ, Karpuzcu ME, Arnold WA, Barber BL, Kaufenberg EF, et al. (2015) Sediment-water distribution of contaminants of emerging concern in a mixed use watershed. Sci Total Environ 1: 896-904.

4. Field KG, Bernhard AE, Brodeur TJ (2003) Molecular approaches to microbiological monitoring: fecal source detection.Environ Monit Assess. 81: 313-26.

5. Gómez-Doñate M, Payán A, Cortés I, Blanch AR, Lucena F, et al. (2011) Isolation of bacteriophage host strains of Bacteroides species suitable for tracking sources of animal faecal pollution in water. Environ Microbiol 13: 1622-31

6. Gourmelon M, Caprais MP, Mieszkin S, Marti R., Wéry N, et al. (2010) Development of microbial and chemical MST tools to identify the origin of the faecal pollution in bathing and shellfish harvesting waters in France. Water Res. 44: 4812-24.

7. Harwood VJ, Staley C, Badgley BD, Borges K, Korajkic A (2014) Microbial source tracking markers for detection of fecal contamination in environmental waters: relationships between pathogens and human health outcomes. FEMS Microbiol Rev 38: 1-40.

8. Lamendella R, Santo Domingo JW, Kelty C, Oerther DB (2008) Bifidobacteria in feces and environmental waters. Appl Environ Microbiol 74: 575-84.

9. Layton A, McKay L, Williams D, Garrett V, Gentry R, et al. (2006) Development of Bacteroides 16S rRNA gene TaqMan-based real-time PCR assays for estimation of total, human, and bovine fecal pollution in water. Appl Environ Microbiol 72: 4214-24.

10. Le-Thi T, Pham-Duc P, Zurbrügg C, Luu-Quoc T, Nguyen-Mai H, et al. (2017) Diarrhea risks by exposure to livestock waste in Vietnam using quantitative microbial risk assessment. Int J Public Health 62: 83-91.

11. Lee DY, Weir SC, Lee H, Trevors JT (2010) Quantitative identification of fecal water pollution sources by TaqMan real-time PCR assays using Bacteroidetes 16S rRNA genetic markers. Appl Microbiol Biotechnol 88: 1373-83.

12. Mallin MA, Ensign SH, Mclver MR, Shank GC, Fowler PK (2001) Demographic, landscape, and meteorological factors controlling the microbial pollution of coastal waters. Hydrobiologia 460: 185-93.

13. Mieszkin S, Furet JP, Corthier G, Gourmelon M (2009) Estimation of pig fecal contamination in a river catchment by real-time PCR using two pig-specific Bacteroidales 16S rRNA genetic markers. Appl Environ Microbiol 75: 3045-54.

14. Nam EH, Ko S, Chae JS, Hwang CY (2013) Charaterization and zoonotic potential of uropathogenic Escherichia coli isolated from dogs. J Microbiol Biotechnol 23: 422-9.

15. Nguyen Thi Phuong Lien, Le Thi Phuong Mai, Nguyen ThiLanAnh, Nguyen ThiThiTho, Do Thi Diem Trinh, et al. (2015) Sero-prevalence of hepatitis E virus in two communes of DuyTien district, Ha Nam province in 2015. Vietnam J Prevent Med 8.

16. Okabe S, Okayama N, Savichtcheva O, Ito T (2007) Quantification of host-specific Bacteroides-Prevotella 16S rRNA genetic markers for assessment of fecal pollution in freshwater. Appl Microbiol Biotechnol 74: 890-901.

17. Puño-Sarmiento J, Medeiros L, Chiconi C, Martins F, Pelayo J, et al. (2013) Detection of diarrheagenic Escherichia coli strains isolated from dogs and cats in Brazil. Vet Microbiol 166: 676-80.

18. Seurinck S, Defoirdt T, Verstraete W, Siciliano SD (2005) Detection and quantification of the human-specific HF183 Bacteroides 16 S rRNA genetic marker with real-time PCR for assessment of human faecal pollution in freshwater. Environ Microbiol 7: 249-59.

19. Simpson JM, Santo Domingo JW, Reasoner DJ (2002) Microbial source tracking: state of the science. EnvionSci Technol 36:5279-88.

20. Soler-Figueroa B, Otero E (2014) The inffluence of rain regimes and nutrient loading on the abundance of two dinoflagellate species in a tropical bioluminescent bay, BahirFosforescente, La Parguera, Puerto Rico. Estuar Cost 38: 84-92.

21. Tram TN, Rebecca T, Phuc PD, Hung NV, Phung DC, Dalsgaard A (2016) Molecular characterization of Cryptosporidumsp. and Giardia sp. contamination in environmental samples in Hanam, Vietnam. Food Waterborne parasitol 3: 13-20. 
22. Huong LQ, Madsen H, Anh le X, Ngoc PT, Dalsgaard A (2014) Hygienic aspects of livestock manure management and biogas systems operated by small-sacle pig farmers in Vietnam. Sci Total Environ 470-1: 53-57.

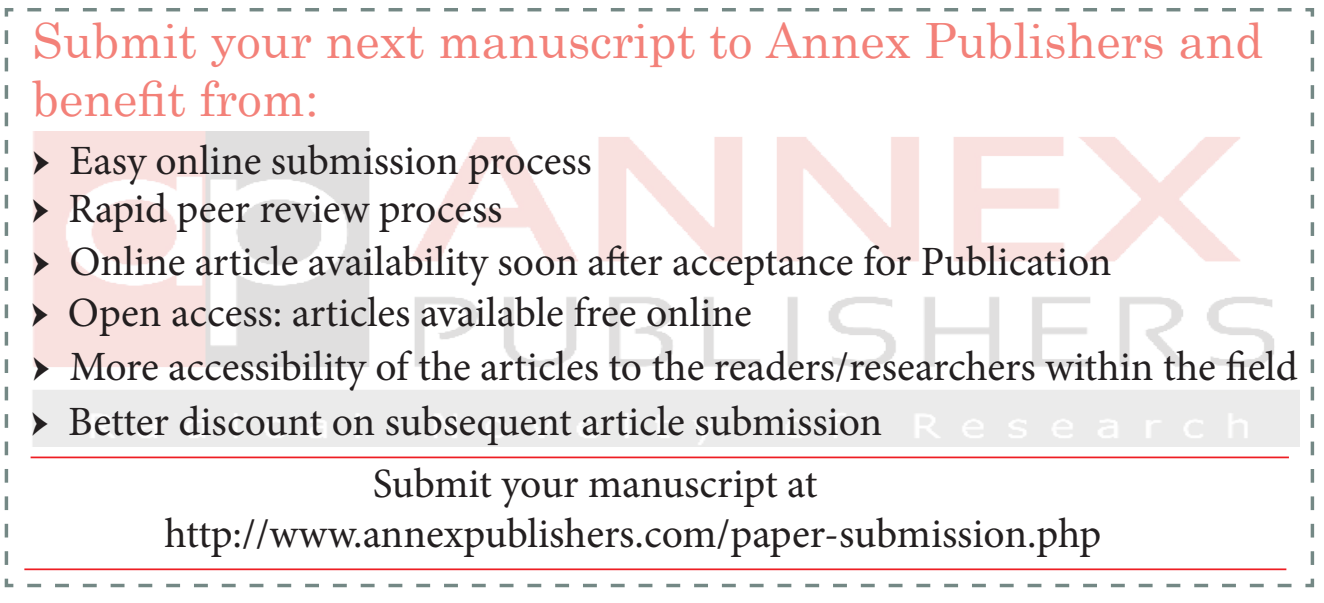

